\title{
Biochemical composition of promising leaves genotypes of buckwheat grown in Himachal Pradesh
}

\author{
Diksha Dogra ${ }^{1}$ and C. P. Awasthi ${ }^{2}$ \\ ${ }^{1}$ Department of Botany, Panjab University, Chandigarh -160014, INDIA \\ ${ }^{2}$ Department of Chemistry and Biochemistry, College of Basic Sciences, CSK Himachal Pradesh Agricultural \\ University , Palampur -176062 (H.P.), INDIA \\ *Corresponding author. E-mail: drdikhadogra@gmail.com
}

Received: August 14, 2016; Revised received: January 31, 2017; Accepted: April 28, 2017

\begin{abstract}
Buckwheat originated from China and being cultivated all over the world, and has become a prominent pseudocereal. Among the pseudocereals (amaranthus, buckwheat and quinoa), buckwheat plant is economically important primarily due to their carbohydrate and protein rich grains, short growth span; besides foliage being used as a green vegetable and commercial source of the glycoside rutin used in medicine. In the present study, an attempt was made to evaluate the biochemical constituents of nutritional and nutraceutical significance of fourteen promising leaves genotypes of common buckwheat grown in Sangla region by following standard procedures. Wide variations in moisture content, crude protein, fat, ash, crude fiber, carbohydrates, ascorbic acid, oxalate and in vitro protein digestibility were observed to range from 87.4 to $92.2 \%, 22.4$ to $30.4 \%, 1.8$ to $3.7 \%, 10.6$ to $15.4 \%, 12.0$ to $13.9 \%, 34.8$ to $42.4 \%, 25.0$ to $29.2 \mathrm{mg} / 100 \mathrm{~g}, 1375$ to $1390 \mathrm{mg} / 100 \mathrm{~g}$ and 53.4 to $65.1 \%$ in that order. The content of minerals such as potassium, phosphorus, calcium, magnesium, zinc, manganese and copper varied from 1767.5 to $2035.0 \mathrm{mg} / 100 \mathrm{~g}, 808$ to $910 \mathrm{mg} / 100 \mathrm{~g}, 394$ to $409 \mathrm{mg} / 100 \mathrm{~g}, 232.0$ to $248.2 \mathrm{mg} / 100 \mathrm{~g}, 3.1$ to $6.1 \mathrm{mg} / 100 \mathrm{~g}$, 20.4 to $29.8 \mathrm{mg} / 100 \mathrm{~g}$ and 0.2 to $1.4 \mathrm{mg} / 100 \mathrm{~g}$ respectively. Based on cumulative grading done in respect of nutritionally desirable quality i.e., protein, ash, crude fiber, carbohydrates, ascorbic acid, in vitro protein digestibility, calcium, phosphorus, iron and oxalate content, the genotype IC-323731 followed by Kullugangetri and VL-27 emerged out to be overall superior versatile cultivars for cultivation under dry temperate climate.
\end{abstract}

Keywords: Ascorbic acid, Buckwheat, Carbohydrates, Oxalates, Protein

\section{INTRODUCTION}

Buckwheat is fast-growing annual, dicotyledonous broad plant belonging to the family Polygonaceae, the "smartweed" family, also called "knotweed" or "buckwheat" family. That is why, the seed of buckwheat is rather a fruit than a grain (the botanical term is "achene") and referred as a pseudocereal (Goncalves et al., 2016).

Buckwheat (FagopyrumesculentumMoench) is a temperate zone plant which originated from Southwest China (Kreft and Germ, 2008). Currently China, Russian Federation, Kazakhstan and Ukraine are the leading producers of buckwheat. The leading continents producers are Europe and Asia (FAOSTAT, 2013).In India, the crop is grown in Western Himalayan states from Jammu and Kashmir in west to Arunachal Pradesh in east. The hilly terrains of Himachal Pradesh represent several diverse eco-geographic pockets which are suitable for the cultivation of hardy crops like small millet type pseudo-cereals like amaranthus, buckwheat and chenopods. In Himachal Pradesh, common buckwheat is grown in Kinnaur, LahulSpiti and Sirmour districts. Since the crop is adapted to temper- ate climate; hence, Himachal Pradesh can play an important role in production of this crop. Buckwheat, also called rhubarb or sorrel, is not a cereal but is usually grouped with cereals due to its ways of cultivation and utilization. This herbaceous erect, annual, meliferous plant is commonly known as kathu, fafra, ogle or bharesh. This pseudo-cereal crop is grown in higher hills and mountains of the state at an altitude of $>1500$ to $4500 \mathrm{msl}$ and covers about 1500 ha area (Phogat and Sharma, 2000).

The vegetable greens are extremely beneficial to the human health and form wonderful source of energy and vitality that powers life on earth. Greens contain a fair amount of good quality protein and are an excellent source of dietary fibre. Besides, freshly picked raw greens are rich source of vitamin $\mathrm{C}$ and nutritionally important minerals, which perform important metabolic functions in the body (Dogra, 2010). In literature, there is scanty information on the nutritional composition of buckwheat leaves. The present study was aimed to identify nutritionally superior leaves genotype of common buckwheat specially with protein and ascorbic acid content which may be useful for further crop improvement programme. 


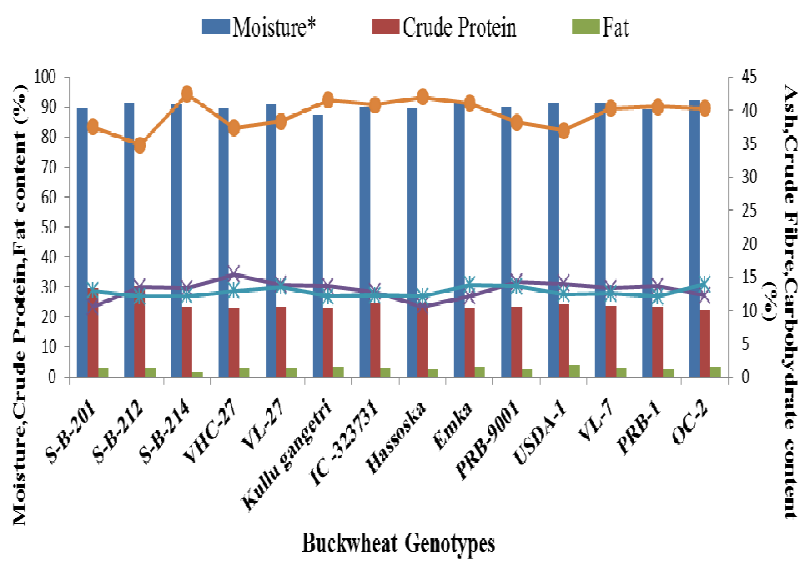

Fig. 1. Variation in biochemical composition of promising genotypes of the buckwheat leaves $(n=3)$ (Values on (\%) dry $w t$.).

\section{MATERIALS AND METHODS}

The leaves samples (200 g) of 14 varieties/genotypes of common buckwheat namelyS-B-201, S-B-212, S-B-214, VHC-27, VL-27, Kullugangetri, IC-323731, Hassoska, Emka, PRB-9001, USDA-1,VL-7, PRB-1 and OC-2 were collected from Mountain Agriculture Research and Extension Centre, Sangla (HP) and evaluated for various biochemical parameters. The finely ground leaves samples of these genotypes were analyzed in triplicate for moisture, crude protein, ash, crude fibre and crude fat by AOAC method (1970) and carbohydrate as per Gopalan et al. (2004). The samples were ground and digested in di-acid mixture (nitric acid: perchloric acid in 3:1 v/v) for the determination of mineral elements namely $\mathrm{Mg}, \mathrm{Ca}, \mathrm{Fe}$ and $\mathrm{Zn}$ on atomic absorption spectrophotometer (model Perkin Elmer, USA) as per Piper (1966). Potassium was determined by flame photometer [model-129; Systronics (India)] whereas phosphorus was determined colorimetrically in the digested samples as per Olsen (1954). The data was analyzed statistically by using analysis of variance (Panse and Sukhatme, 1984). In order to identify multipurpose versatile cultivars of buckwheat, rating (ranking) of various genotypes was done based on nutritionally desirable traits i.e., protein, carbohydrates, calcium, iron content as adopted by Dogra (2010).

\section{RESULTS AND DISCUSSION}

The biochemical analysis of buckwheat leaves of various genotypes revealed that moisture content in genotypes varied from 87.4 to $92.2 \%$ with maximum in genotype OC-2 and lowest in Kullugangetri (Fig.1). The moisture content roughly reflects the degree of maturity and accumulation of fibre in the crop plants. The protein content varied significantly from 22.4 to $30.4 \%$ with highest content in genotype S-B-212, followed by genotypes IC-323731and Hassoska and lowest in genotype OC-2. The crude fat, an estimate of

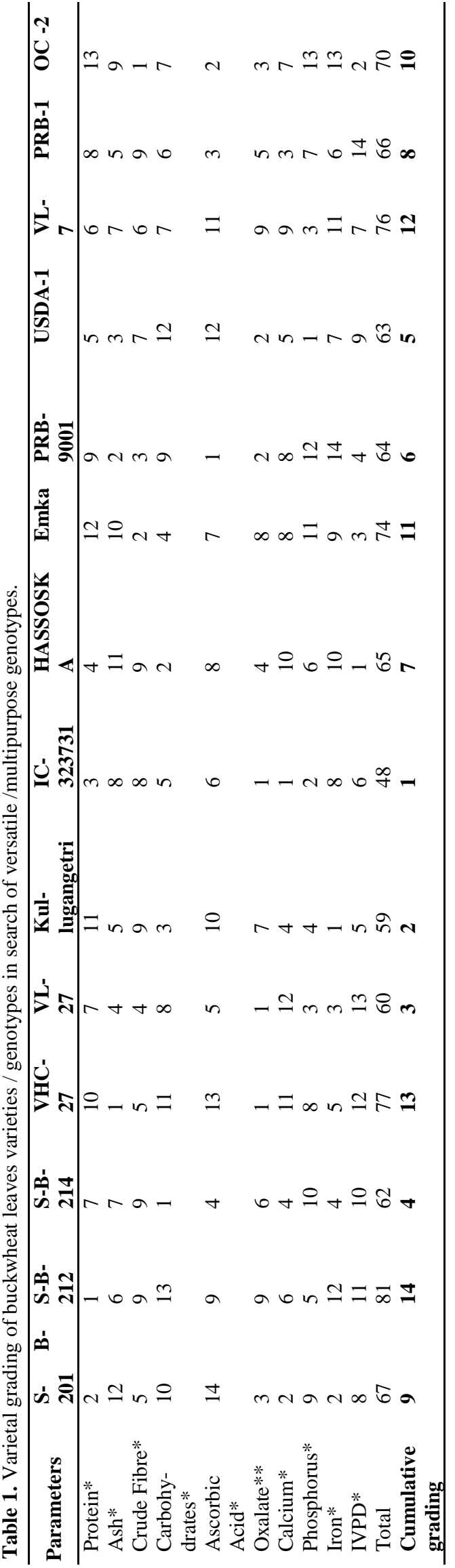


Diksha Dogra and C. P. Awasthi / J. Appl. \& Nat. Sci. 9 (2): 875 - 878 (2017)

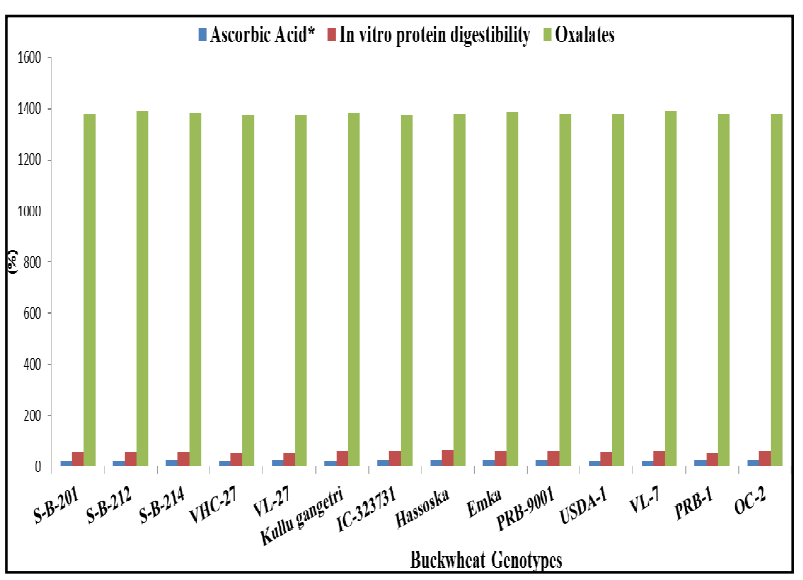

Fig. 2. Variation in biochemical composition of promising genotypes of the buckwheat leaves (Values on (\%) dry wt.). *Values on (\%) fresh weight basis.

the total fat content, was highest in genotype USDA-1 and lowest in S-B-214. The genotype VHC-27 had highest ash content while Hassoska had lowest ash content with overall range 10.6 to $15.4 \%$. The crude fibre content in genotypes varied from 12 to $13.9 \%$ with maximum in genotype OC-2 and minimum in S-B -212. The carbohydrates form a major part of food which helps in building body strength by generating energy. The carbohydrate content in genotypes varied from 34.8 to $42.4 \%$ with maximum in S-B-214 and minimum in S-B-212. Our results are in agreement with Dietrych-Szostak and Ploszynski (1988) who reported 8.3 per cent ash, 10.1 per cent fiber, 3.5 per cent fat and 13.5 per cent protein on dry weight basis in the leaves of buckwheat plants. However, Lahanov et al. (2004) reported 24.3 per cent crude protein and 14.1 per cent ash content in leaves of Fagopyrumesculentum ssp. esculentum. Gopalan et al. (2004) reported that spinach leaves contained 92.1 per cent moisture content. Leiber et al. (2012) observed crude protein and ether extract in buckwheat leaves 242 and $32 \mathrm{~g} / \mathrm{kg}$ dry matter basis. Vojtiskova et al. (2012) reported that moisture, crude protein and fat content in buckwheat leaves 7.5, 22.7 and $3.1 \%$, accordingly. Variation noticed in these parameters by and large in accordance with the values reported by with Dietrych-Szostak and Ploszynski (1986) and Farooq and Tahir (1989).

The status of ascorbic acid content in buckwheat varieties / genotypes was evaluated and relevant data are presented in Fig.2. The overall variation in this parameter was observed from 25.0 to 29.2 per cent among various varieties / genotypes. The genotype PRB 9001 showed the highest ascorbic acid content followed by OC-2, PRB-1, S-B-214, VL-27, IC323731, Emka, Hassoska and S-B-212 (statistically at par). However, the lowest value was noticed in the genotype S-B-201. The perusal of literature revealed variation in ascorbic acid content from 10 to 117 $\mathrm{mg} / 100 \mathrm{~g}$ in fresh spinach leaves (Siener et al., 2006 and Gopalan et al.,2004).

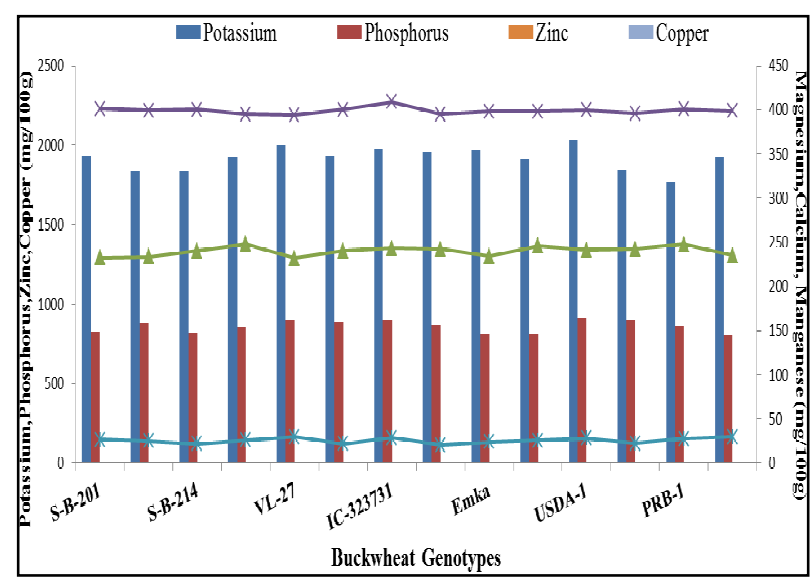

Fig.3. Variation in mineral composition of promising genotypes of the buckwheat leaves (Values on dry wt.).

The data showing variability in the in vitro protein digestibility in the leaves of different buckwheat varieties / genotypes are presented in Fig. 2. Significant variation in respect of this parameter among various varieties/genotypes was observed to range from 53.4 to 65.1 per cent. The genotypes Hassoska showed the highest value, whereas the genotypes OC2, Emka and PRB-9001 possessed the next higher value on this aspect. However, the lowest value was observed in the variety PRB-1. with Dietrych-Szostak and Ploszynski (1986)reported47.5 per cent in vitro digestibility in leaves and stemsof buckwheat plant residues and hulls. Ly and Preston (2001) have reported 68.8 per cent in vitro digestibility in Ipomoea aquatica. Low protein digestibility due to high crude fibre content and tannin content (Eggum et al., 1981). The extent of variation observed for in vitro protein digestibility of the present work are in conformity with the findings of above investigators on this aspect.

The status of oxalate content in the leaves of different buckwheat varieties / genotypes was evaluated and pertinent data on this aspect are depicted in Fig. 2. Significant variation in oxalate content of different buckwheat genotypes was observed to range from 1375 to $1390 \mathrm{mg} / 100 \mathrm{~g}$. Among different varieties / genotypes the lowest oxalate content was found in VHC-27, IC-323731 and VL-27. However, the highest value for oxalate content was noticed in the genotypes S-B-212 followed by VL-7. The released varieties PRB-9001, USDA-1, PRB-1 and OC-2 exhibited 1379, 1379,1380 and $1380 \mathrm{mg} / 100 \mathrm{~g}$ oxalate content, respectively.

Siener et al.(2006) reported the oxalate content as $1391 \mathrm{mg} / 100 \mathrm{~g}$ in raw leaves of Sorrel Rumex acetosa $\mathrm{L}$ var. hortensis belonging to Polygonaceae family, whereas soluble oxalate content ranged from 800 to $1257 \mathrm{mg} / 100 \mathrm{~g}$ and total oxalate content ranged from 1634 to $2285 \mathrm{mg} / 100 \mathrm{~g}$ in raw leaves of spinach (Spinaciaoleracea), respectively and the findings of the accompanying work fall within this range of varia- 
tion of these vegetable greens.

The mineral analysis of buckwheat genotypes revealed that potassium content ranged from 1767.5 to $2035 \mathrm{mg}$ $100 \mathrm{~g}$-1 with lowest and highest values in genotype PRB-1 and USDA-1, respectively (Fig.3). Phosphorus content varied from 808 (in OC-2) to 910 (USDA-1); magnesium content from 232 (VL-27) to 248.2 (VHC27); calcium content from 394 (VL-27) to 409 (IC323731); zinc content from 3.1 (S-B-214) to 6.1 (Emka); manganese content from 20.4 (Hassoska) to 29.8 (OC-2) and Copper content from 0.2 (VL-27) to 1.4 (S-B-201); mg $100 \mathrm{~g} \mathrm{g-1} \mathrm{respectively.} \mathrm{Ikeda} \mathrm{et} \mathrm{al.}$ (1999) analyzed calcium, magnesium, phosphorus, potassium, zinc, copper and manganese content of buckwheat leaves and found the status of these minerals as 894.2, 305, 1132, 5139, 6.69, 0.27 and 38.81 $\mathrm{mg} / 100 \mathrm{~g}$, accordingly on dry weight basis and results of the present work are in consonance with the findings of these workers. Similar trend of variations in the mineral composition among buckwheat genotypes have been reported by with Dietrych-Szostak and Ploszynski (1986, 1988).

The grading of various genotypes with respect to the prominent desirable quality characters viz., crude protein, oil, ash, crude fibre, calcium, phosphorus and iron contents is presented in Table 1 . The genotypes IC323731 proved to be prominent genotypes followed by Kullugangetri, VL-27, S-B-214 and USDA-1 in order of cumulative ranking. The genotypic grading made it possible to identify multipurpose genotypes suited for their direct inclusion in the human diet.

\section{Conclusion}

Buckwheat is a plant from the family of Polygonaceae. Buckwheat leaves contains protein (30.4\%), carbohydrates (42.4\%), ascorbic acid (29.2 mg/100g), oxalate $(1390 \mathrm{mg} / 100 \mathrm{~g})$, potassium $(2035 \mathrm{mg} / 100 \mathrm{~g})$, phosphorus (910 mg/100g), calcium (409mg/100g), magnesium $(248.2 \mathrm{mg} / 100 \mathrm{~g})$ and zinc $(6.1 \mathrm{mg} / 100 \mathrm{~g})$. Based on cumulative grading done in respect of nutritionally desirable quality, the genotype IC-323731 followed by Kullugangetri and VL-27 emerged out to be overall superior versatile cultivars for cultivation under dry temperate climate.

\section{REFERENCES}

A. O. A. C. (1970). Official Methods of Analysis of Association of Official Analytical Chemists. $11^{\text {th }}$ edition. Washington, D.C.

Dietrych-Szostak, D. and Ploszynski, M. (1986). Chemical composition and feeding value of buckwheat hulls and harvest residues. In: Proceedings of the $3{ }^{\text {rd International }}$ symposium on Buckwheat, Poland. P.149 - 155

Dietrych-Szostak, D. and Ploszynski, M. (1988). The value of hulls and postharvest residues of buckwheat in feeding tests with mice. Fagopyrum, 8: 18-19

Dogra, D. (2010). Biochemical Evaluation of Buckwheat (FagopyrumesculentumMoench) Genotypes. Ph.D. thesis. Department of Chemistry and Biochemistry, CSK Himachal Pradesh Krishi Vishvavidyalaya, Palampur, India.

Eggum, B. O., Kreft, I. and Javornik, B. (1981). Chemical composition and proteins quality of buckwheat (Fagopyrum esculentum Moench). Qualitas Plantarum Plant Foods for Human Nutrition, 30 : 175 -179

FAOSTAT (Food and Agricultural Organization of the United Nations Statistics) (2013). FAO Statistical Databases. Accessed online at: http://faostat.fao.org/. FAO, Rome, Italy.

Farooq, S. and Tahir, I. (1989). Leaf composition in some buckwheat cultivars (FagopyrumGaertn.) grown in Kashmir. Fagopyrum, 9: 68-70

Goncalves, F.M.F., Dabiage, R.R., DaSilva, R.M.G., Porto, P.P., Yoshihara, E. and Peixoto, E.C.T.D.M. (2016). Fagopyrumesculentum Moench: A crop with many purposes in agriculture and human nutrition. African Journal of Agricultural Research, 11(12): 983-989

Gopalan, C., Rama, B.V. and Balsubramanian, S.C.(2004). Nutritive value of Indian foods. National Institute of Nutrition (ICMR), Hyderabad. Pp. 52-83

Ikeda, S., Yamashita, Y. and Kreft, I. (1999). Mineral composition of buckwheat by- products and its processing charactristics to konjak preparation. Fagopyrum, 16:8994

Kreft, I. and Germ, M. (2008). Organically grown buckwheat as a healthy food and a source of natural antioxidants. In: $2^{\text {nd }}$ Mediterranean Conference on Organic agriculture, Dubrovnik, April, 2008.

Lahanov, A. P., Muzalevskaja, R. S., Shelepina, N. V. and Gorkova, I. V. (2004). Biochemical characteristics of some species of genus Fagopyrum Mill. In: Proceedings of the $9^{\text {th }}$ International Symposium on Buckwheat, Prague. P. 604- 611

Leiber, F., Kunz, C. and Kreuzer, M. (2012). Influence of different morphological parts of buckwheat (Fagopyrumesculentum) and its major secondary metabolite rumen fermentation in vitro. Czech Journal of Animal Science, 57 (1): 10-18

Ly, J. and Preston, T. R. (2001). In vitro estimates of nitrogen digestibility for pigs and water - soluble nitrogen are correlated in tropical forage feeds. Livestock Research for rural development, 13(1)

Olsen, S. R., Cole, C. V., Walanable, F. S. and Dean, L. A. (1954). Estimation of available phosphorus in soils by extraction with sodium bicarbonate. Methods of Soil Analysis, Part 2 (CA Black eds.).

Panse, V. G. and Sukhatme, P. V. (1984). Statistical methods for agricultural workers, ICAR, New Delhi.

Phogat, B. S. and Sharma, G. D. (2000). Underutilized food crops: their uses, adaptation and production technology. National Bureau of Plant Genetic Resources, New Delhi. P 12

Piper, C. S. (1966). Methods for the ashing of plant materials (chapter-II). In: Soil and Plant Analysis. Hans Publishers, Nicol Road, Bombay. 258 -275

Siener, R., Honow, R., Seidler, A., Voss, S. and Hesse, A. (2006). Oxalate contents of species of the Polygonaceae, Amaranthaceae and Chenopodiaceae families. Food Chemistry 98: 220-224

Vojtiskova, P., Kmentova, K., Kuban, V. and Kracmar, S. (2012). Chemical composition of buckwheat plant 